\title{
The Relation between the two Phenomeno- logical Categories Initiation and Sacrifice as Exemplified by the Norse Myth of Ódinn on the Tree
}

Many articles have been devoted to the Old Norse myth which relates how Odin was hanging from a tree for nine nights without being offered food or drink. This paper does not pretend to deal with all the problems concerning this myth, most of which are primarily of philological interest. As a matter of fact, what I am going to do here is nothing more than discuss whether we are faced with an initiation or a sacrifice in these strophes. To do so, however, demands that we go into the general phenomenological framework in relation to the two categories in order to decide the distinctive features characterizing each one of them.

The strophes read as follows:

138 Veit ek at ek hekk

vindgæmeiði á

nætr allar níu,

geiri undaðr

ok gefinn Óðni,

sjálfr sjálfum mér,

á peim meiði,

er manngi veit,

hvers hann af rótum renn.

139 Við hleifi mik sældu

né við̀ hornigi,

nysta ek niðr,

nam ek upp rúnar,

opandi nam, fell ek aptr paðan.
138 I know that I hung on the windswept tree for nine full nights, wounded with a spear and given to Oờinn, myself to myself; on that tree of which none know from what roots it rises.

139 They did not comfort me with bread, and not with the drinking horn; I peered downward, I grasped the 'runes', screeching I grasped them; I fell back from there. 
140 Fimbulljód níu nam ek af enum frægja syni Bolpórs, Bestlu f̨ður, ok ek drykk of gat ens dýra mjaðar, ausinn Óðreri.

141 Pá nam ek frævask ok fróðr vera ok vaxa ok vel hafask; orð mér af orði orðs leitaði, verk mér af verki verks leitaði.
140 I learned nine mighty songs from the famous son of Bölthór, father of Bestla, and I got a drink of the precious mead, I was sprinkled with Oðrerir.

141 Then I began to be fruitful and to be fertile, to grow and to prosper; one word sought another word from me; one deed sought another deed from me. (Translation by Turville-Petre)

Although it is certain that Hávamál, as it is known from the Codex Regius, is a compilation of several autonomous poems, there is no reason to believe that the four strophes under discussion have not always made up a unit. It is thus reasonable to treat the myth more or less in isolation from the rest of the poem.

The question we are going to investigate here is, as mentioned, whether we are facing a sacrifice or an initiation. Both possibilities have been proposed, and some scholars have even believed that the strophes deal with an exemplary myth which has served directly as a model for some ritual (Klingenberg 1972: $134 \mathrm{ff}$. and 1973: $169 \mathrm{ff}$.). Below we shall return to this question. The crucial problem seems to be the exact meaning of the words ok gefinn Óðni siálfr siálfom mér. How are we to translate the word gefinn? Does it mean "initiated" or "sacrificed"? The first meaning is supported by Sijmons and Gering (1906-31/3: 149), van Hamel (1932: 264), Pipping (1928: 9), F. Ström (1947: 61), Hunke (1952: 69), and perhaps most distinctly by Höfler (1934: $232 \mathrm{ff}$.), whereas the latter is supported by Turville-Petre (1964: 50), Beck (1967: $134 \mathrm{ff}$.), Sauvé (1970: 180), and probably also implicitly by Talley (1974: $63 \mathrm{ff}$.). Many scholars have viewed van Hamel's explanation of the problems concerning this myth as essentially correct. He claimed the myth to be about Odin actualizing his magical power by suffering martyrdom; and magic should

1 Although van Hamel is a bit confusing in his choice of terminology, it is obvious that his distinction between "martyrdom" and "sacrifice" is parallel to the distinction between "initiation" and "sacrifice". Concerning this distinction, he wrote:

"It lies not so much in the circumstance that in martyrdom one offers something of oneself, whereas we may sacrifice anything we like, in the majority of cases something that is not part and parcel of ourselves. This is only a consequence of a deeper 
be understood as an attempt to communicate with the dead which is then achieved during the nine nights of suffering (Hamel 1932: 288). This is clearly some kind of initiation", whether "magical" or "religious". The American scholar Jere Fleck, who has worked in detail with Odin's hanging from the tree, refrains from committing himself on this point in that he uses both designations; and without any kind of theoretical discussion he argues for both the one and the other phenomenon (Fleck 1968: $101 \mathrm{ff}$. and 1971$)^{3}$. There may be a point in that, as we shall see below, but Fleck, however, does not seem to have noticed it. Anyway, it is not fair to pretend that there is no problem at all involved, especially since van Hamel's interpretation has been severely criticized by those scholars who maintain that the phenomenon with which we are confronted is sacrifice. Further, it must be noticed that in the phenomenology of religion the two phenomena are almost mutually exclusive ${ }^{4}$.

One of the most brilliant analyses of the four strophes in Háv. is that by J. L. Sauvé who is very critical towards van Hamel's insistence on the difference between "martyrdom" and "sacrifice". Sauvé, however, is

difference. He who suffers martyrdom in order to obtain a certain object, extorts it from the actual possessor, whose magical power is overcome by the greater magical power of his opponent. Through martyrdom one actualizes his own magical power and, if one is only able to sustain the torture long enough, the possessor of the desired object will be compelled to surrender. But in the case of sacrifice the possessor can only be moved to grant the demand from his free will. Martyrdom is practiced against blind powers, such as the elements or magic, whereas a sacrifice is offered to a god who takes an interest in mankind generally or in a particular favourite. In appearence, however, the two will often have much in common and easily get mixed up" (1932: 266).

It is thus not quite clear at which phenomenological category van Hamel is aiming with his "martyrdom", but it is obvious that we are dealing with a tradition which accepts a radical distinction between religion and magic. This distinction is hardly tenable today, mainly because it is not operational. However, it seems reasonable to parallel "martyrdom" with certain kinds of initiation in that van Hamel agrees with Sijmons and Gering when they maintain that gefinn Ó $\partial_{n i}$ ought to be translated as "dem Óðinn geweiht". For a critical discussion of van Hamel, see Sauvé 1970: $179 \mathrm{f}$.

${ }^{2}$ For a characterization of the phenomenon of initiation, see Schjødt 1986.

${ }^{3}$ The closest Fleck comes to it in making up his mind is 1971: 398, where he wrote: "Oððinn's ritual inversion contains not only the standard elements of the initiation, but also incorporates features of a ritual sacrifice". Which of the elements, however, are seen as belonging to either complex is a problem he does not touch upon.

* See, for instance, F. Ström who maintains that fasting cannot belong to sacrifice, since it does not increase the value of the object (1947: 61), a statement which, however, is softened later on (1947:73), as we are told that both the self-hanging and sacrifices for Odin have a common denominator in the divination: "De sakrala och de magiska linjerna sammanstråla $i$ en offerritual, vars huvudsyfte har varit att med det döende offret som medium tyda de tecken, som forma framtidens händelsemönster" . Concerning the statement that fasting cannot belong to sacrifices, see below. 
clearly in favor of seeing the rite as a sacrifice, and does not pay attention to the category of initiation. He is strongly influenced by Dumézil and uses much comparative material to support his theory. Thus he tries to compare the myth with the Indian purushamedha and also with the description by Adam of Bremen of the sacrifices in Uppsala which involve people being killed by hanging. We must look a little closer at Sauvé's argument, since, as mentioned, he has been more explicitly critical towards van Hamel than has been the case with other scholars. Sauvé says:

The assertion that Odin is martyred, not sacrificed, pays no attention to the obvious and hardly inconsequential fact that he suffers precisely the same ritual death as might befall one of his human sacrificial victims. Odin does indeed die a ritual death by means of which he appropriates the power of death, symbolized in the runic magic that raises the dead to momentary eloquence. (1970: 180)

In this statement there are elements from both the terminology of sacrifice as well as that of initiation, and it seems in general that even Sauve has not given sufficient reflection to the relation between the two categories. This is most conspicuous in his treatment of the relationship between Odin as the mythic model and the human sacrificial victims, in which it is difficult to maintain that the latter benefit from the action. This relationship is dealt with in relation to the purushamedha, where the identity between victim and sacrificer is stressed. But still, the relation between Odin and his human sacrificial victims seems to be more complicated than Sauve is willing to admit.

As mentioned, it is first and foremost the description by Adam of Bremen which Sauvé compares to Odin's rite. In this description, however, there are differences as well as similarities in relation to Háv. Looking first at the similarities, we notice that the number nine is dominant in both sources: Odin's trial is going on during nine nights; the rituals in Uppsala take place every ninth year; nine victims of different species are sacrificed; the sacrifices last for nine days (schol. 141). The hanging itself is also common to both sources, i.e. both Odin and the victims in Uppsala are hanged from trees. It may also be a parallel that both Odin and the victims are wounded: Odin with a spear, whereas the victims are placed in the trees only after their blood has been given to the gods ${ }^{5}$. Finally the trees are sacred in both sources (although this is not said explicitly

\footnotetext{
5 The combination of hanging and spear wound can be found in several sources of the North (e.g. the Vikar episode which we shall turn to below and Hálfssaga oc Hálfsrekka chap. 8). See also Ward 1970.
} 
in Háv., there is no doubt that the tree in 138 is the most sacred of all trees, the world tree Yggdrasil).

But there are differences, too, in the two sources. The parallel just mentioned might as well be viewed as a difference, since it seems, by Adam, that the trees in the grove in Uppsala cannot be seen as cultic parallels to Yggdrasil. This is due to the information in schol. 138 concerning a tree which is no doubt the cultic counterpart of Yggdrasil, as this is described in Gylfaginning chap. 8 and Voluspá st. 19, both as to the size and the eternal greenness. This tree is standing close to a source, just as the world tree can be located in a position close to the source of Mimir or Urd (Vsp. 19); and this tree is probably not identical to any of the trees in the grove, their sacredness being primarily due to the death and decay of the victims. But even if this difference may be due to the general problems with the source value of Adam's work, there are others of a more serious kind. Most problematic among them is the fact that in Adam's description we are told nothing that can be compared to Háv. 139-141. This means that it is only part of the myth which has parallels in the cultic framework, as far as we can see from Adam's information. We could even maintain that the parallels we do find are relatively unimportant and are only to be found at the level of details, whereas the essential part, i.e., the combination of ritual death, acquisition of numinous knowledge, and a return to the world of the living has no counterpart in Adam's text $^{6}$. Nevertheless, a fact is mentioned in the end of chapter 27 which might indicate that fertility, i.e., notions which - although it is rather dubious - might correspond to Odin's return to life, also played some part in the sacrificial feasts in Uppsala, namely, that the songs being performed during the feast were "several and indecent" (neniae multiplices et inhonestae), indicating that these songs which Adam did not want to relate in any detail probably had a sexual content. This, however, brings associations with sacrifices to the gods of physical fertility rather than to Odin. On the other hand, it cannot be denied that sacrifices by strangling were especially performed among the Indo-Europeans in connection with the gods of the first function, i.e., Odin in the North (Ward 1970: 123 ff.). It is not possible, then, to dismiss the relation between the sacrificial victims in Uppsala and Odin, but at the same time we must emphasize that the descriptions do not allow us to draw any certain conclusions concerning the kind of similarity at the semantic level between Odin on

6 Beck 1967: 173 treats the similarities between the two texts, but does not mention the differences. Seen in relation to Sauvé's argument, however, it must be admitted that "some kind of" connection in the symbolic expression is at stake. 
the tree and those victims who were sacrificed to him.

There is another incident which, no doubt, corresponds to Odin's performance, namely the killing of King Vikar, described in two sources, namely, Gautreks saga chap. 7 and in Gesta Danorum, p. 152 (the edition of Olrik and Ræder). In spite of some important differences between the two sources in their account of Starkad, their descriptions of the killing of Vikar show only minor differences. The significant context in relation to this subject is that $O$ din wants a human sacrifice in return for letting the wind blow in order that the ship with Vikar and his men can go on. As the lot falls on the king himself, the men agree that they will make a token sacrifice. Starkad, to whom Odin has promised three spans of life and other gifts, is the one who is going to perform the sacrifice. As he says, "now I give you to Odin" ( $n u$ gef $e k p i k$ Ódni) the harmless reed he is using turns into a spear, the stump Vikar is standing on falls from his feet, the calf's gut which is around Vikar's neck turns into a strong rope, and the twig to which the gut was tied becomes a real branch. Saxo's account is slightly different, but the result in both sources is that Vikar is killed as a sacrificial victim at the command of Odin.

There is no doubt that this sacrifice is a sacrifice to Odin, and that the way it is performed is quite in accord with Odin hanging in Háv. 138 . But again we see that there is no parallel to $139-141$, which once again accentuates the problems posed, when we are to compare the notions in Háv. and those lying behind Vikar's sacrifice. Thus, we are not able to say anything about whether the victims in Uppsala and Vikar are in any symbolic way believed to have gained knowledge through their hanging. But in both sources, the phenomenon we are dealing with seems to be best described as a do-ut-des sacrifice, especially in connection with Vikar, where it is said almost explicitly that Starkad and Odin are making a contract, according to which Starkad shall have three spans of life if he sends Vikar to Odin. It is of interest that, according to Gautreks saga, the words Starkad uses as he kills Vikar are "nú gef ek pik Óðni", with the verb gefa used in connection with a do-ut-des sacrifice? ${ }^{7}$.

Thus, it is not so easy to compare the myth of Odin's hanging on the one hand and the rituals connected with the sacrifices in Uppsala and the killing of Vikar on the other. Nevertheless, it cannot be denied that there are similarities at the level of symbolic expression: the number nine, the

7 Beck (1967: 106) maintains that the verb gefa cannot be used as a formula of dedication in relation to animal sacrifices. On the other hand she mentions several examples in which it is used in connection with human sacrifices (p. $96 \mathrm{ff}$ ) which suggests that these sacrifices have a special position in the ideology of the Northmen. 
combination of hanging and stabbing, and the handing over of the object to Odin. Sauvé does indeed put forward some strong arguments, and his conclusion, therefore, seems convincing. He says:

Odin achieved a mighty victory over death when he dangled from the world tree for nine nights, and secured possession of the powerful runes, effective over the dead. (1970: 190)

It is reasonable to believe that this conclusion is close to reality, but the question is whether it is basically different from that of van Hamel, showing that Odin through his martyrdom is trying to communicate with the dead and the underworld. Van Hamel, too, saw that the manifestations of "martyrdom" and "sacrifice" might be difficult to distinguish, although, as he wrote, the conceptions behind the two phenomena were quite different (1932: 272). However, it does not seem so obvious that these conceptions are that different, if we cannot accept the definitions of van Hamel which are influenced by the evolutionistic framework in which he analyzed the myth (e.g. 1932: 266). There are indeed several points in symbolism, meaning, and function which are quite similar in both initiations and dout-des sacrifices. If we thus compare the quoted passage from Sauvé's article with the words of the French mythologist Renauld-Krantz, it is easy to see some important similarities:

Dans la souffrance le monde lui devient interieur et ses secrets se révèlent à lui. Tel est à mon avis le sens psychologique et mystique du martyre volontaire d'Odin. La souffrance qu'il ressent a donc une valeur initiatique et doit être rapprochée de celle qui est toujours infligée dans les ceremonies d'initiation. (1972: $80 \mathrm{f}$.)

and further:

Or ce qu'obtient Odin par le martyre qu'il s'inflige, c'est le savoir magique symbolisé par les runes. (1972: 82)

Both Sauvé and Renauld-Krantz thus see the runes and that knowledge of the other world with which they supply the subject as the essential goal of the action, whether they look upon it as a sacrifice or an initiation.

This leads to a more theoretical discussion of the structure of the two categories of rituals. In both the do-ut-des sacrifice and in the initiation, we notice four essential elements: 1) The subject who sends 2) an object to a 3) recipient who sends back 4) another object in return. This structure is evident in the do-ut-des sacrifices, whereas it is not quite so obvious in connection with initiations. 
The realization of this structure is not new, since it was already investigated in the beginning of this century (Hubert and Mauss 1964: 100 f.), and the reason that it has not been applied to the myth of Odin on the tree is simply that here we have an identity between three elements $(1,2,3)$ which are almost always separated in the cult ${ }^{8}$. Thus in the rituals, the subject is one or more humans, the object can be anything living or dead, and the recipient is one or more supernatural beings. The return-object may be anything: nice weather, health, food, fertility, etc.; and it may be numinous knowledge exemplified in the runes "effective over the dead" and the living, for that matter. In Háv. we also recognize these four elements, but here Odin is the subject as well as the object and the recipient, while the return-object is the runes and other kinds of numinous knowledge.

The structure, then, is parallel to that of an ordinary do-ut-des sacrifice. But van Hamel noticed that certain elements in the myth could not belong to a sacrifice, i.e., the suffering of the cold wind and of hunger and thirst (Hamel 1932: 267 ff. see also F. Ström 1947: 61), which would only make sense in an act of martyrdom. Such an assertion, however, would have to be constructed from argumenta ex silentio, and using these is very problematic in the case of old Norse religion. Sauvé seems to have shown some parallels from India which contradict the statement as well. Further, it is important to note that Odin is both subject and object, and that it is quite common that the sacrificer has to observe certain rules before he performs the ritual in order to separate him from his ordinary position.

Whatever the right explanation is, we must now proceed to investigate how the structure of initiation is related to the structure of the myth and to the structure of do-ut-des sacrifices.

During initiations, the initiate "gives" himself to something which is normally a social group or a socially (and religiously) separated category. This group or category is often under the protection of a certain god $^{9}$ whose "property" they become during initiation. It is therefore reasonable to maintain that this god is the recipient of the initiates. In return they get the rights and duties which are connected with this particular group,

\footnotetext{
${ }^{8}$ How separated they are, in fact, could be discussed, since several scholars have correctly observed that the victim possesses part of the power of the subject and thus is part of the subject (Widengren 1969: 285); see also below.

9 In most religious cultures we know different kinds of groups of people with special relationships to certain gods. In the North it has been shown clearly by Otto Höfler that the Männerbünde had a close connection to Odin (Hö甘ler 1934).
} 
and eventually knowledge of these rights and duties. Moreover, it is often necessary for the individual to acquire some kind of magical knowledge in order to be able to fulfil the functions of his new status, a knowledge which is probably most clearly seen in connection with initiations of the shamanic type. This indicates that the elements subject, object, recipient, and return object are also at stake in relation to initiation rituals; and here, in contrast to the do-ut-des sacrifices, it is the rule that subject and object are identical. In initiation it is thus the subject who gives himself (as an object) to the recipient, which may be a social group or a supernatural being (perhaps symbolically representing the group). The recipient, on the other hand, gives in return knowledge - a knowledge which aims at the attention of the practical functions of the new status and at the same time provides different kinds of numinous knowledge.

This structure is easy to recognize in the myth of Odin on the tree as well as in the structure of sacrifice, with the notable difference that most sacrifices operate with a distinction between subject and object, whereas the initiation rituals present us with an identification between the two. Speaking about "self sacrifice", however, there is no way of distinguishing the two categories; not in relation to the structure of the sequence or the horizontal structure, anyway.

As a provisional conclusion we can state, then, that the structure we face in the myth of Odin including a subject who is lacking some desired object and for that reason gives "something" to "somebody" who then negates the initial lack, can be seen in do-ut-des sacrifices as well as in initiations. This fact makes it understandable that scholars have classified Odin's act in both categories.

However, there are other levels than the structural one which make up a basis for a classification. In criticizing the Australian anthropologist W. E. H. Stanner, who discussed the criteria for distinguishing the two categories among aboriginals, van Baal noted that the object during sacrifice is destroyed, whereas in initiation it benefits from the ritual (Baal 1971: 189) ${ }^{10}$. We have to ask, therefore, whether Odin as the object is destroyed. Is he killed or is it only a token sacrifice, such as Höfler, for instance, proposed? On the one hand Höfler emphasized the necessity of interpreting the hanging as a symbolic death, and on the other he wrote: "Scheintötungen aber, die als Scheinopfer aufgebaut waren, kennen wir

${ }^{10}$ However, we must once again emphasize that it is appropriate at an analytical level to make a distinction between subject and object, and again, therefore, we must ask whether it is the subject or the object who benefits from the initiation ritual. We shall return to the problem below. 
besonders in einer Kategorie zur Genüge: bei den Initiationsriten" (Höfler 1934: 237). Höfler thus succeeds in combining sacrifice and initiation, in drawing our attention to the symbolic death which is so often part of initiation rituals. In relation to Odin's position in Háv., it means that the four elements hanging, stabbing with a spear, starving, and exposure to the wind, separately or taken together, are symbols of death; or, in other words: the treatment which Odin is exposed to and which initiates all over the world are exposed to can be understood as equivalent to the destruction of the object in sacrifice. For, just as the object of sacrifice through its destruction is transformed to a state in which it is able to reach the gods, so it is necessary for the initiates to change their state to that of liminality in the sense of van Gennep and Victor Turner in order to reach contact with the "other world". And this is most often obtained through a kind of maltreatment symbolizing death. Neither on the symbolic level, then, does there seem to be any significant difference between the two categories in relation to the destruction of the object in that we may, in a certain way, see the initiation as a symbolic self sacrifice with a symbolic destruction to match. But just as the symbolical meaning is of great importance here, it is problematic when, for instance, Höfler emphasizes the importance of drawing a distinction between a real death and a symbolic one in relation to Háv. (Höfler 1934: 232 and 236): in a mythical context, this distinction is of no importance, since a "real" death and a symbolic death, from a semantic point of view, are exactly the same ${ }^{11}$.

The significant element in Háv. is that Odin is transformed. Whether or not he is destroyed is of lesser importance. If death, however, in itself must be seen as a destruction, then of course he is destroyed, just as is the case in all rituals of initiation, operating with the symbolism of death and rebirth. But in that case, the criterion which van Baal used in order to distinguish

\footnotetext{
11 In the rituals, of course, it is different. Here it may be decisive in the cat egorization whether the "victim" is actually killed or just goes through a symbolic death (not to speak of the difference in the social and psychological implications). In relation to the distinction between sacrifice and initiation, this is of course also important, since a "real" hanging must be an act belonging to sacrifice, whereas a symbolic killing of a human being must belong to the category of initiation. It must be maintained, however; that a "real" death in the mythic universe does not have to be any different from a symbolic death in the ritual universe, since in the myths there are no problems connected with a return to the world of the living; the actors are gods or humans who are protected by divine intervention. In relation to the ideology of the religious people themselves, it must be maintained, too, that in ritual a symbolic death is a death. In relation to the myth of Odin, we should not, therefore, make any sharp distinction between a "real" and a symbolic death.
} 
between "sacrifice" and "anointment" loses its meaning in that it is wrong to maintain that "in the latter the action is to the benefit of the object, in the former the object is made a victim". The object is always a "victim", while the subject always "benefits", both in sacrifices and initiations. And this also goes for Odin's acquisition of numinous knowledge. The problem is that Odin is both subject and object: he benefits as subject, but is destroyed as object. For analytical reasons, it has been convenient here to draw a distinction between subject and object, but, as we have seen, the two are identical both in Háv. and in initiations in general. And even in do-ut-des sacrifices, it is not possible to maintain that subject and object are totally distinct. Although this is the case physically, it is important to note that besides the declared goal of the ritual, which is to gain something - the return object - through the sacrificed object, it is often the case that symbolically the object is regarded as being part of the subject himself, as is known in the institution of gift-giving in almost all archaic cultures ${ }^{12}$. Giving includes an expression of friendship and creates bonds between subject and recipient ${ }^{13}$, burdening the latter with the obligation of giving a return gift (e.g. Háv. 42 and 145, see also Baal 1976: $163 \mathrm{ff}$.). In sacrifices, the gift functions, then, as a kind of mediator between man and the supernatural (Hubert and Mauss 1964: 11) since man is giving part of himself. Whereas the communication between this world and the other in sacrifice is thus "indirect" so far as an object more or less different from the subject is invested (we may speak of a pars-prototo relation), in the initiation it is "direct" because the subject himself becomes more or less "supernatural" during the liminal phase. He gets directly, as a whole individual, into contact with the supernatural. Thus it is possible, of course, to maintain the distinction between initiation and sacrifice, but it is important to note the parallel structure in which it is only the relation between subject and object that differs: identification and difference.

In connection with the strophes in Háv. it has been ascertained in this paper that it is not reasonable to argue, as Sauvé does, that the act of Odin must be classified as a sacrifice and not as an initiation. The identity between subject and object definitely points rather to the category of initiation. On the other hand, it should be admitted that, in the face of the

\footnotetext{
12 See Baal 1975: 26 ff. and 52 ff., and explicitly in Baal 1976: 174: "Up to an extent the sacrificer is identical with the victim". The most famous and perhaps best analysis of the gift institution is still Marcel Mauss' Essay sur le don.

${ }^{13}$ That this is the case also in the North is obvious from many examples (see Hamre 1981: 653 ff.), which among others has been analyzed by Grønbech (1955/2: 49 ff.).
} 
mythical example, it is extremely difficult even to keep the identification between subject and object as the decisive point, since what seems to be an initiation in the myth, the god being both subject and object, might become the mythical model for sacrifices, such as Sauvé himself has shown. Another criterion for a distinction which can only be mentioned here, but which no doubt is of some importance, is the notion of numinous knowledge as the return object. In initiations, this object will always be knowledge which brings the subject to an irreversible higher level, whereas this is not the case in sacrifices.

\section{References Cited}

Baal, J. van

1971 Symbols for Communication. An Introduction to the Anthropological Study of Religion. Assen: Van Gorcum.

1975 Reciprocity and the Position of Women. Assen: Van Gorcum.

1976 Offering, Sacrifice, and Gift. Numen 23: 161-178.

Beck, I.

1967 Studien zur Erscheinungsform des heidnischen Opfers nach altnordischen Quellen. München. [Diss.]

Fleck, J.

1968 Die Wissensbegegnung in der altgermanischen Religion. München. [Diss.]

1971 Oðinn's Self-sacrifice. A New Interpretation. Scandinavian Studies 43: 119$142,385-413$.

Grønbech, V.

1955 Vor Folkeæt i Oldtiden, 2 vols. København: Gyldendal. [2. ed.]

Hamel, A. G. van

1932 Odinn Hanging on the Tree. Acta Philologica Scandinavica 7: 260-288.

Hamre, $\mathbf{L}$.

1981 Gåve. In: Kulturhistorisk leksikon for nordisk middelalder; vol. 5; cols. 653-661. [København]: Rosenkilde og Bagger. [2. ed.]

Hubert, H., and M. Mauss

1964 Sacrifice - its Nature and Function. London: Cohen \& West.

Hunke, W.

1952 Odins Geburt. In: H. Schneider (Hrsg.), Edda, Skalden, Saga. Festschrift zur 70. Geburtstag F. Genzmer; pp. 68-41. Heidelberg: Winter.

Höfler, $O$.

1934 Kultische Geheimbünde der Germanen. Frankfurt: Diesterweg.

Klingenberg, $\mathbf{H}$.

1972 Hávamál. Bedeutungs- und Gestaltwechsel eines Motivs. In: Oskar Bandle (Hrsg.), Festschrift für Siegfried Gutenbrunner zum 65. Geburtstag am 26. Mai 1971. Überreicht von seinen Freunden und Kollegen; pp. 114-144. Heidelberg: Winter.

1973 Runenschrift - Schriftdenken - Runeninschriften. Heidelberg: Winter. 


\section{Pipping, R.}

1928 Oden i galgen. Helsingfors: Svenska litteratursällskapet i Finland. (Studier i Nordisk Filologi, 18/2)

\section{Renauld-Krantz, [P.]}

1972 Structures de la Mythologie Nordique. Paris: G.-P. Maisonneuve \& Larose.

Sauvé, J. L.

1970 The Divine Victim: Aspects of Human Sacrifice in Viking Scandinavia and Vedic India. In: J. Puhvel (ed.), Myth and Law among the Indo-Europeans. Studies in Indo-European Comparative Mythology; pp. 173-191. Berkeley: University of California Press.

Schjødt, J. P.

1986 Initiation and the Classification of Rituals. Temenos 22: 93-108.

Sijmons, B., and $H$. Gering

1906-31 Die Lieder der Edda; 4 vols. Halle: Waisenhaus.

Ström, F.

1947 Den döendes makt och Odin i trädet. Göteborgs Högskolas Arsskrift 53/1: 1-90.

Talley, J. E.

1974 Runes, Mandrakes, and Gallows. In: G. J. Larson (ed.), Myth in Indo-European Antiquity; pp. 157-168. Berkeley: University of California Press.

Turville-Petre, E. O. G.

1964 Myth and Religion of the North. New York: Weidenfeld \& Nicholson.

Ward, D. J.

1970 The Threefold Death: An Indo-European Trifunctional Sacrifice? In J. Puhvel (ed.), Myth and Law among the Indo-Europeans. Studies in Indo-European Comparative Mythology; pp. 123-142. Berkeley: University of California Press.

Widengren, $\mathrm{G}$.

1969 Religionsphänomenologie. Berlin: Walter de Gruyter \& Co. 